\title{
PENGARUH WORK-FAMILY CONFLICT TERHADAP TURNOVER INTENTION MELALUI KOMITMEN ORGANISASI
}

\author{
Meilaty Finthariasari \\ mheyfinta@umb.ac.id \\ Sri Ekowati \\ Furqonti Ranidiah \\ Rina Yuniarti \\ Universitas Muhammadiyah Bengkulu \\ Muchlis \\ Universitas Airlangga Surabaya
}

\begin{abstract}
This studi was conducted based on the existing research gap and the gap phenomenon. This studi aims to analyze the work family conflict and turnover intention through mediating organizational commitment of female sharia private banking employees in the city of Bengkulu during the Covid-19 pandemi. This studi was conducted at five private Islamic banks in the city of Bengkulu, with a sample of 117 female respondents. Data were processed using LISREL analysis tool version 8.70. The results found that work family conflict had a significant positive effect on turnover intention with a standardized value of $47 \%$, work family conflict had a significant negative effect on organizational commitment with a standardized value of $49 \%$, organizational commitment had a significant negative effect on turnover intention with a standardized value of $42 \%$, and organizational commitment is able to mediate between work family conflict against turnover intention with a standardized value of $21 \%$ (positive). Family conflict that occurred during the Covid-19 pandemi confirmed higher than work conflict. Work family also has a negative impact on organizational commitment. While the results of the studi relate to the mediating role of organizational commitment, it indicates a positive influence between work family conflict and turnover intention.
\end{abstract}

Key words: banking; pandemi Covid-19; work family conflict; commitment organizational; turnover intention.

\begin{abstract}
ABSTRAK
Studi ini dilakukan berdasarkan adanya riset gap dan fenomena gap yang ada. Studi ini bertujuan untuk menganalisis work family conflict dan turnover intention melalui mediasi komitmen organisasi karyawan wanita perbankan swasta syariah di Kota Bengkulu pada masa pandemi Covid-19. Studi ini dilakukan pada lima bank swasta syariah yang ada di Kota Bengkulu, yaitu: Bank Mega Syariah, Bank Muamalat, Bank Danamon Syariah, Bank Sinarmas Syariah, Bank Pundi Syariah, dengan jumlah sampel 117 responden wanita. Data diolah dengan menggunakan alat analisis LISREL versi 8.70. Peneliti melakukan uji validitas dan reliabilitas terhadap masing-masing indikator dan konstruk yang digunakan. Dari hasil uji hipotesis yang dilakukan, peneliti menemukan bahwa work family conflict memiliki pengaruh positif signifikan terhadap turnover intention dengan nilai standardized $47 \%$, work family conflict memiliki pengaruh negatif signifikan terhadap komitmen organisasi dengan nilai standardized $49 \%$, komitmen organisasi memiliki pengaruh negatif signifikan terhadap turnover intention dengan nilai standardized $42 \%$, dan komitmen organisasi mampu memediasi antara work family conflict terhadap turnover intention dengan nilai standardized 21\% (positif).
\end{abstract}

Kata kunci: perbankan; pandemi Covid-19; work-family conflict; komitmen organisasi; turnover intention

\section{PENDAHULUAN}

Pergeseran paradigma mengenai wanita bekerja mengurus rumah menjadi sebuah isu yang menarik saat ini. Pasangan suami-istri yang sama-sama bekerja mencari nafkah sering kali ditemui. Wanita memiliki ke- 
sempatan kerja yang sama dengan laki-laki. Bahkan tidak sedikit pula wanita (istri) memiliki pendapatan atau posisi pekerjaan yang lebih baik dari suaminya.

Kesempatan bekerja serta berkarir bagi wanita yang telah memiliki keluarga sering kali memunculkan permasalahanhan dalam rumah tangga. Wanita yang bekerja di luar rumah dan di dalam rumah mengurusi rumah tangga merupakan tuntutan pekerjaan yang berbeda yang harus dijalani. Namun ketika peran pekerjaan di lingkungan kantor dan peran pekerjaan di rumah tidak dapat berjalan seimbang dapat memicu terjadinya konflik antar kedua peran tersebut.

Di lingkungan perbankan, karyawan wanita memang cenderung lebih banyak jumlahnya jika dibandingkan dengan karya wan laki-laki, sehingga wanita yang memiliki peran ganda cenderung akan menemui konflik peran pekerjaan dan keluarga (work family conflict). Data mencatat seperempat dari karyawan bank adalah wanita (Wage Institution, 2010). Sebagai wanita karir, banyak tantangan yang dihadapi berkaitan dengan bidang pekerjaan dan keluarga, terlebih pada masa pandemi Covid-19 saat ini.

Pada masa pandemi Covid-19 di Kota Bengkulu membuat banyak bank mengurangi jam operasional di kantor dengan cara mengatur jadwal bekerja karyawan dengan hari kerja yang bergantian. Hal ini artinya banyak pekerjaan yang dialihkan secara online. Namun untuk karyawan wanita yang telah menikah, bekerja di rumah tidak membuat mereka menjadi santai, namun menurut mereka bekerja secara online lebih banyak menemui kendala karena fasilitas dari beberapa dokumen yang lain tidak didukung secara online, sementara saat bekerja di rumah juga terdapat ganguan lain dari anggota keluarga sehingga membuat mereka menjadi tidak fokus dan rentan dengan stres. Hal ini juga membuat waktu yang dimiliki untuk bekerja lebih banyak tersita walaupun dilakukan di rumah. Selain masalah tersebut, bagi para karyawan wanita yang telah berkeluarga ini pun sempat mengalami stres dengan beberapa deadline dan target yang tetap berjalan meskipun pekerjaan dilakukan work from home.

Pekerjaan sebagai karyawan bank merupakan pekerjaan dengan tingkat stres yang cukup tinggi. Berdasarkan survey awal yang telah dilakukan, beberapa karyawan bank sering bekerja lembur, sehingga dapat dipahami bahwa bagi mereka yang sering lembur ini, sangat sulit untuk membagi waktu antara pekerjaan dan keluarga. Permasalahan lain yang muncul saat wabah pandemi Covid-19 ini berlangsung adalah ketika harus tetap menjaga kondisi badan karena setiap karyawan memiliki resiko yang tinggi terinfeksi virus Covid-19 karena terkadang ada beberapa karyawan yang masih berinteraksi dengan nasabah dan debitur. Selain itu juga, mereka harus dapat menjaga kesehatan keluarga (anak dan suami). Hal ini menjadi tantangan yang begitu sulit yang harus dihadapi sebagai seorang wanita karir dan sebagai seorang istri dimusim wabah pandemi Covid-19 ini.

Permasalahan yang lain muncul ketika pengeluaran yang membengkak saat pandemi ini terjadi sementara beberapa insentif yang tidak dibayar karena bekerja dirumah. Permasalahan ini menimbulkan konflik pada keluarga karena kebutuhan meningkat sementara tuntutan pekerjaan masih harus tetap berjalan. Hal ini tentunya tidak dirasakan bagi karyawan Bank Besar BUMN dan Bank Swasta Konvensional lainnya yang telah tumbuh besar, karena bagi mereka tidak ada bedanya besaran pendapatan mereka meski saat wabah Covid-19 ini terjadi. Kondisi ini sangat dirasakan bagi karyawan Bank Swasta Syariah, dimana Bank Swasta Syariah di wilayah Kota Bengkulu masih dalam kategori sedang berkembang, sehingga masih sangat butuh kerja keras dan komitmen yang besar dari para karyawan untuk membesarkan perusahaan ini.

Beberapa konflik yang dihadapi karyawan wanita perbankan berkaitan dengan 
pekerjaan dan keluarga menjadi isu menarik untuk diteliti. Work-family conflict merupakan bentuk konflik antar-peran yang terjadi ketika energi, waktu, atau tuntutan perilaku dari konflik peran pekerjaan dengan keluarga atau peran kehidupan pribadi. Konflik pekerjaan-keluarga menjadi semakin penting dalam masyarakat karena memiliki konsekuensi penting untuk pekerjaan, non-kerja, dan hasil pribadi seperti produktivitas, pergantian, kesejahteraan keluarga, kesehatan, dan stress (Kossek et al., 2017). Work-family conflict yang muncul dapat memicu terjadinya turnover intention (Alsam et al., 2013). Hom et al. (2017) mengartikan turnover intention sebagai keinginan berpindah yang secara sadar dan disengaja untuk meninggalkan organisasi.

Sementara jika turnover intention terjadi dengan cukup tinggi maka dikhawatirkan akan dapat memicu terjadinya turnover itu sendiri. Turnover yang terjadi pada masa pandemi dan pasca pandemi akan sangat merugikan pihak perusahaan karena perusahaan akan mengeluarkan biaya lebih untuk merekrut kembali karyawan. Beberapa literatur yang berfokus terutama pada konflik pekerjaan-keluarga (WFC) dan konfliknya efek negatif yang terdokumentasi dengan baik pada sikap dan kinerja, sekaligus meningkatkan perilaku turnover intention karyawan (Ngo-Henha, 2017). Untuk dapat menekan turnover intention dan mengimbangi permasalahan yang muncul ini, menurut Finthariasari (2019) dapat dilihat dari sisi komitmen organisasi yang dimiliki oleh para karyawan perusahaan, dimana komitmen organisasi merupakan komitmen yang timbul dalam diri karyawan dan merupakan penilaian terhadap perannya terhadap organisasi (Al Jabri dan Ghazzawi, 2019).

Penelitian ini dilandaskan atas temuan riset pada Aboobaker et al. (2017) dalam risetnya menyarankan penelitian selanjutnya untuk menganalisis work family confict dan turnover intention dengan menggunakan variabel mediasi atau moderasi lain yang dapat menekan turnover itu sendiri. Selain berlandarkan atas riset gap, penelitian ini juga diangkat karena terdapat permasalahn pada lingkungan perbankan swasta syariah yang ada di Kota Bengkulu.

Penelitian ini dilakukan dengan tujuan untuk menganalisis pengaruh work-family conflict terhadap turnover intention melalui komitmen organisasi pada karyawan wanita Bank Swasta Syariah di Kota Bengkulu.

Studi ini penting dilakukan untuk mengidentifikasi permasalahan work-family conflict yang ada pada karyawan bank swasta syariah dan hubungannya dengan turnover intention di musim pandemi Covid19 ini, sehingga perusahaan dapat dengan tepat membuat kebijakan yang dapat mendukung kehidupan pekerjaan dan kehidupan keluarga. Hal ini penting untuk dipahami bagi perusahaan Bank swasta syariah untuk dapat menciptakan keseimbangan dalam bekerja dan dalam mengelola kehidupan keluarga dengan kebijakan yang tepat dari perusahaan.

\section{TINJAUAN TEORETIS}

\section{Pengaruh Work-Family Conflict terhadap Komitmen Organisasi}

Work-family conflict merupakan konflik yang timbul antara pekerjaan dan peran nonpekerjaan (yaitu, komunitas, waktu luang, kelompok teman, dan lain-lain.) yang tak terhindarkan bagi kebanyakan orang yang bekerja saat ini (Wilson dan Baumann, 2014). Sebuah konflik peran dimana terdapat berbagai tekanan peran antara bidang pekerjaan dan keluarga yang secara keseluruhan tidak berjalan normal dan tidak seiring jalannya dalam bentuk beberapa hal, artinya fokus dalam peran dibidang pekerjaan (keluarga) menjadi lebih sulit karena adanya peran dalam bidang keluarga (pekerjaan). Workfamily conflict pertama kali diperkenalkan oleh Kopelmen et al. (1983). Work-family conflict merupakan konflik pekerjaan dimana seseorang mengalami tekanan adanya ketidakseimbangan antara pekerjaan dan keluarga (Ekowati, 2018). Work-family conflict didefinisikan oleh Greenhaus dan Allen (2011) dalam bentuk: 
Pertama, konflik pekerjaan ke keluarga (work-family conflict), indikatornya: tuntutan pekerjaan menganggu keluarga, pekerjaan mengurangi keterlibatan diri dalam keluarga, pekerjaan mengganggu keinginan keluarga, pekerjaan menghambat kegiatan dalam keluarga, dan konflik antara komitmen pekerjaan dan tanggung jawab keluarga.

Kedua, konflik keluarga ke pekerjaan (family-work conflict), indikatornya: tuntutan keluarga menganggu pekerjaan, pekerjaan tertunda karena keluarga, tidak dapat menyelesaikan pekerjaan dikantor, keluarga mengganggu tanggung jawab terhadap pekerjaan, adanya ketegangan dalam keluarga.

Work family conflict dapat berhubungan dengan komitmen organisasi. Menurut Robbins dan Judge (2015) mendefinisikan komitmen organisasi adalah suatu keadaan dimana seorang karyawan memihak organisasi tertentu serta tujuan dan keinginannya untuk mempertahankan keanggotaan dalam organisasi. Komitmen organisasi memiliki tiga komponen berbeda yang sesuai dengan keadaan psikologis yang berbeda. Allen dan Meyer (2013) mengembangkan tiga komponen komitmen dan menerbitkannya di "Tinjauan Manajemen Sumber Daya Manusia" tahun 1990. Tiga komponen tersebut diantaranya:

1. Affective Commitment (AC). AC didefinisikan sebagai keterikatan emosional positif karyawan terhadap organisasi. Meyer dan Allen mematok $A C$ sebagai komponen komitmen "keinginan" organisasi.

2. Contituance Commitment (CC). CC adalah komponen kebutuhan atau keuntungan versus kerugian dalam bekerja di organisasi. Hal ini berkaitan dengan teori taruhan sampingan (side bet theory), keuntungan dan kerugian yang mungkin terjadi jika seseorang tetap tinggal atau meninggalkan organisasi.

3. Normative Commitment (NC). Karyawan dengan $O C$ (organizational commitment) yang lebih besar memiliki peluang lebih besar untuk berkontribusi terhadap keberhasilan organisasi dan juga akan mengalami tingkat kepuasan kerja yang lebih tinggi. Tingkat kepuasan kerja yang tinggi, pada gilirannya, mengurangi perputaran karyawan dan meningkatkan kemampuan organisasi untuk merekrut dan mempertahankan bakat.

Hubungan antara work family conflict yang dipicu oleh ketidakpuasan dalam bekerja dan rumah tangga, yang dapat meimbulkan stres, sehingga komitmen organisasi seseorang akan berkurang (Benligiray dan Sönmez, 2012). Studi lain yang membuktikan bahwa work family conflict dapat menurunkan komitmen organisasi seorang karyawan diantaranya (Greenhaus dan Powell, 2012; Halbesleben et al., 2014; Higgins et al., 2010; Ashforth et al., 2014; Allen et al., 2012). Berdasarkan pada hasil penelitian sebelumnya maka:

$\mathrm{H}_{1}$ : Work family conflict memiliki pengaruh negatif terhadap komitmen organisasi.

\section{Pengaruh Work-Family Conflict terhadap Turnover Intention}

Work-family conflik berkaitan erat dengan turnover intention. Perubahan kondisi lingkungan pekerjaan membuat isu ini selalu menarik untuk diteliti mengenai kaitan antara work-family conflict terhadap turnover intention (Aboobaker et al., 2017). Al-Zawahreh dan Al-Madi (2012), Rathakrishnan et al. (2016) menyatakan bahwa turnover intention merupakan bentuk tidak eksplisit serta mempunyai kaitan positif dengan turnover yang sebenarnya.

Untuk mengukur turnover intention, Ngo-Henha (2017) menyatakan bahwa terdapat tiga dimensi, yaitu: intention to quit, search another job, dan thinking of quit. Finthariasari (2018) menyatakan tiga dimensi diatas kedalam beberapa indikator, yaitu:

Pertama, intention to quit, indikatornya: berpikir keluar dari organisasi karena merasa diperlakukan tidak adil, berpikir untuk keluar dari organisasi dalam waktu dekat, dan berpikir untuk keluar organisasi sehingga saya mulai sering absen dan mangkir. 
Kedua, search another job, indikatornya: berkeinginan untuk mencari lowongan pekerjaan baru ditempat lain, mencari pekerjaan yang lebih baik lagi sesuai dengan jenjang pendidikan, mencari pekerjaan lain karena pekerjaan ini sangat berat.

Ketiga, thinking of quit, indikatornya: berkeinginan untuk meninggalkan perusahaan dalam beberapa bulan mendatang, berkeinginan meninggalkan organisasi dalam beberapa bulan mendatang karena organisasi ini tidak memiliki kebijakan yang jelas, berkeinginan untuk meninggalkan perusahaan karena adanya peluang kerja di organisasi lainnya yang lebih baik.

Turnover intention merupakan hak bagi setiap individu dalam menentukan pilihan terhadap pekerjaannya, apakah tetap bekerja atau keluar dari perusahaan tersebut. Turnover intention merupakan proses awal dari terbentuknya perilaku menarik diri (withdrawal) dalam dunia kerja (Lepold, 2018). Lepold juga mengemukakan turnover sebagai suatu proses digantikan oleh dimana karyawan meninggalkan organisasi dan posisi pekerjaan tersebut harus orang lain.

Pada penelitian kontemporer dan praktik manajerial, keseimbangan kehidupan kerja (work-life balance) telah mendapatkan perhatian yang lebih besar karena beberapa faktor work-family conflict yang rendah bersumber dari keseimbangan kehidupan kerja (Amstad et al., 2011), sementara tingginya work-family conflict melalui konflik kerja-keluarga (WFC) dan konflik keluargakerja (FWC) yang dialami oleh karyawan akan dapat memicu stres kerja, kelelahan, dan niat untuk meninggalkan (turnover intention) yang dapat berujung pada turnover karyawan (Mansour dan Tremblay, 2018).

Work family conflict tidak memiliki hubungan yang signifikan dengan kinerja pekerjaan (Karatepe dan Uludag, 2018), kemudian secara umum konflik kerjakeluarga (WFC), dan khususnya FWC memiliki efek negatif pada kepuasan hidup (Zhao et al., 2011; Greenhaus dan Powell, 2016; Yanchus et al., 2010). Sementara faktor kepuasan hidup ini merupakam faktor utama yang dapat memprediksi turnover intention. Noermijati et al. (2020) menyatakan work family conflict pada karyawan perempuan Papua yang bekerja di PT FreeportIndonesia memiliki pengaruh positif signifikan terhadap turnover intention. Penelitian tentang kekuatan hubungan antara konflik kerja-keluarga karyawan (work-family conflict atau WFC) dan konflik keluarga-kerja (family-work conflict) dan niat mereka untuk meninggalkan organisasi telah dilakukan oleh Aboobaker et al. (2017). Aboobaker et al. (2017) menemukan bahwa 0,403, menjelaskan 40,3 persen dari varians dalam turnover intention adalah variabel konflik pekerjaan-keluarga dan konflik keluargapekerjaan. Berdasarkan pada hasil penelitian sebelumnya maka:

$\mathrm{H}_{2}$ : Work family conflict memiliki pengaruh positif terhadap turnover intention.

\section{Pengaruh Komitmen Organisasi (Organi- zational Commitment) terhadap Turnover Intention}

Komitmen organisasi merupakan sebuah rasa identifikasi, loyalitas, dan keterlibatan yang diungkapkan oleh seorang karyawan terhadap organisasi atau unit organisasi. Karyawan yang memiliki komitmen organisasi yang baik, akan mampu bertahan pada perusahaan dan tidak memiliki niat untuk berpindah (turnover intention). Al Jabri dan Ghazzawi (2019) menyatakan bahwa organisasi akan mampu mencapai visi dan misi serta tujuannya jika adanya komitmen dari anggota organisasi. $O C$ secara umum diartikan sebagai sikap yang menunjukkan loyalitas karyawan dan merupakan proses yang berkelanjutan tentang bagaimana seorang anggota organisasi mengekspresikan perhatian mereka kepada kesuksesan dan kebaikan organisasinya. OC yang kuat ditandai dengan: (1) Sebuah dukungan dan penerimaan tujuan dan nilai organisasi, (2) Sebuah keinginan untuk mengerahkan usaha yang cukup atas nama organisasi, dan (3) Sebuah keinginan untuk tetap dengan organisasi. Allen dan Meyer 
(2013) mengembangkan tiga komponen komitmen:

Pertama, effective commitment, terdiri dari: keterikatan emosional, menerima nilai organisasi, dan mendukung tujuan organisasi.

Kedua, contituance commitment, terdiri dari: kemauan untuk tetap tinggal dalam organisasi atau perusahaan, ketergantungan atau kebutuhan terhadap organisasi, dan merasa rugi keluar dari perusahaan.

Ketiga, normative commitment, terdiri dari: perasaan bertanggung jawab pada organisasi, mendukung norma organisasi, dan merasa berkewajiban untuk tetap tinggal pada organisasi tertentu.

Penelitian mengenai pengaruh komitmen organisasi terhadap turnover intention telah dilakukan oleh (Finthariasari, 2019) terhadap 311 responden karyawan bank konvensional di wilayah Bengkulu Indonesia. Hasil penelitian menyatakan bahwa komitmen organisasi memiliki pengaruh negatif signifikan terhadap turnover intention karyawan. Dalam penelitian Finthariasari, dimensi Normative commitment memiliki nilai yang paling kuat dalam memprediksi komitmen organisasi sehingga dimensi ini pula yang dapat memperkuat prediksi terhadap turnover intention. Begitupula dengan Aydogdu dan Asikgil (2011) menyatakan tiga dimensi komitmen organisasi dan turnover intention memiliki hubungan yang signifikan dan negative. Labrague et al. (2018) melakukan penelitian pada 160 perawat di Filipina, menyimpulkan bahwa perawat berkomitmen cukup untuk organisasi tetapi ragu-ragu apakah berkeinginan untuk meninggalkan organisasi mereka atau tidak.

Usia, jenis kelamin, pendidikan, pangkat, dan pengalaman kerja perawat berkorelasi signifikan dengan komitmen organisasi, usia dan pendidikan perawat ber korelasi signifikan dengan turnover-inten tion. Selanjutnya, komitmen organisasi perawat berkorelasi negatif dengan turnover intention. Berdasarkan pada hasil penelitian sebelumnya maka:
$\mathrm{H}_{3}$ : Komitmen organisasi memiliki pengaruh negatif terhadap turnover intention.

\section{Pengaruh Work Family Conflict terhadap Turnover Intention melalui Komitmen Organisasi}

Dalam studi yang dilakukan oleh peneliti saat ini, berbeda dengan studi sebelumnya, dimana peneliti akan mengajukan variabel komitmen organisasi sebagai variabel mediasi untuk memprediksi pengaruh work family conflict terhadap turnover intention. Work family conflict yang terjadi pada karyawan karena faktor ketidak seimbangan antara peran dalam bidang pekerjaan di kantor dan peran dalam keluarga. Work family conflict dapat memicu terjadinya turnover intention. Berbeda dengan komitmen organisasi, dimana komitmen organisasi dikatakan dapat meredam atau menurunkan turnover intention. Berbagai studi yang telah dilakukan mengemukakan bahwa work family conflict yang tinggi akan mempengaruhi positif signifikan terhadap tingkat turnover intention karyawan (Aboobaker et al., 2017; Mansour dan Tremblay, 2018). Kemudian studi mengenai pengaruh komitmen organisasi terhadap turnover intention telah dilakukan oleh, Labrague et al., (2018), Aydogdu dan Asikgil (2011), dimana hasil penelitian menyatakan bahwa variabel komitmen organisasi memiliki pengaruh negative signifikan terhadap turnover intention. Sehingga hipotesis yang diajukan adalah:

$\mathrm{H}_{4}$ : Work family conflict memiliki pengaruh terhadap turnover intention melalui komitmen organisasi.

\section{METODE PENELITIAN \\ Sampel Penelitian}

Sesuai dengan latar belakang penelitian yang telah dipaparkan di bagian pendahuluan di atas, maka sampel dalam penelitian ini adalah karyawan wanita yang telah berstatus menikah pada Bank swasta syariah yang ada di Kota Bengkulu, yang berjumlah 117 orang. Responden akan 
didata jenis dan karakteristik responden yang terdiri dari usia, lama bekerja diperusahaan, dan usia perkawinan. Adapun sampel penelitian yaitu terdiri dari karyawan: 1) Bank Mega Syariah sebanyak 22 karyawan, 2) Bank Muamalat sebanyak 32 karyawan, 3) Bank Danamon Syariah sebanyak 28 karyawan, 4) Bank Sinarmas Syariah sebanyak 20 karyawan, 5) Bank Pundi Syariah sebanyak 15 karyawan.

\section{Tehnik Pengumpulan Data}

Data yang telah terkumpul dari responden yang telah mengisi kuesioner mandiri secara online mengenai work family conflict (kuesioner modifikasi dari peneliti sebelumnya ((Netemeyer et al., 2015), komitmen organisasi dan turnover intention (Finthariasari, 2019), kemudian diolah dengan menggunakan alat analisis LISREL versi 8.70. Skala penilaian jawaban responden menggunakan skala LIKERT 5 point ( $1=$ sangat tidak setuju hingga $5=$ sangat setuju).

\section{Metode Analisis}

Tahap awal pengolahan adalah menguji tingkat validitas melalui pemeriksaan Confirmatory Factor Analysis atau CFA untuk setiap item pernyataan atau indikator penelitian, kemudian menganalisis reliabilitas melalui CR. Tahap berikutnya adalah analisis deskriptif data, menganalisis model persamaan structural (SEM), dan menganalisis uji kesesuaian model dan Goodness Of Fit (menggunakan indikator chi square, RMSEA, GFI, AGFI, CFI), serta uji hipotesis dengan menganalisis nilai $t$ value yang diperhitungan dalam penelitian ini. Tahap akhir adalah melakukan wawancara secara daring kepada beberapa responden untuk mengkonfirmasi hasil temuan yang ada dalam penelitian ini.

\section{ANALISIS DAN PEMBAHASAN \\ Hasil \\ Karakteristik Sampel}

Tabel 1

Karakteristik Sampel $(n=117)$

\begin{tabular}{|c|c|c|c|}
\hline \multicolumn{2}{|c|}{ The characteristics of Demographic } & Frequency & $\%$ \\
\hline \multirow{4}{*}{ Usia } & $25-35$ tahun & 28 & 23.93 \\
\hline & $31-45$ tahun & 39 & 33.33 \\
\hline & $46-55$ tahun & 31 & 26.50 \\
\hline & $>55$ tahun & 19 & 16.24 \\
\hline \multirow{4}{*}{$\begin{array}{l}\text { Masa kerja di } \\
\text { perusahaan }\end{array}$} & $1 \mathrm{~s} / \mathrm{d} 10$ tahun & 35 & 29.91 \\
\hline & 11 s/d 20 tahun & 40 & 34.19 \\
\hline & $21 \mathrm{~s} / \mathrm{d} 30$ tahun & 29 & 24.79 \\
\hline & $>30$ tahun & 13 & 11.11 \\
\hline \multirow{4}{*}{$\begin{array}{l}\text { Usia } \\
\text { Perkawinan }\end{array}$} & $1 \mathrm{~s} / \mathrm{d} 10$ tahun & 32 & 27.35 \\
\hline & 11 s/d 20 tahun & 34 & 29.06 \\
\hline & $21 \mathrm{~s} / \mathrm{d} 30$ tahun & 32 & 27.35 \\
\hline & $>30$ tahun & 19 & 16.24 \\
\hline
\end{tabular}

Sumber: data diolah, 2020.

Analisis data di atas bahwa karakteristik responden dalam penelitian ini terdiri dari kategori usia didominasi oleh karyawan barusia 31-45 tahun sebanyak 39 orang
(33,33\%), dengan masa bekerja $11 \mathrm{~s} / \mathrm{d} 20$ tahun sebanyak 40 orang $(34,19 \%)$, dan dengan usia perkawinan $11 \mathrm{~s} / \mathrm{d} 20$ tahun sebanyak 34 orang $(29,06 \%)$. 
Uji Validitas dan Reliabilitas

Tabel 2

Hasil Perhitungan Confirmatory Factor Analysis \& Reliability Of Indicators

\begin{tabular}{|c|c|c|c|c|c|}
\hline \multicolumn{2}{|c|}{ Model Pengukuran } & \multirow{2}{*}{$\begin{array}{l}\text { Factor } \\
\text { Loading }\end{array}$} & \multirow{2}{*}{$\begin{array}{c}\text { Measure } \\
\text { ment } \\
\text { Error }\end{array}$} & \multicolumn{2}{|c|}{ Reliability } \\
\hline Laten Variable & $\begin{array}{l}\text { Manifest } \\
\text { Variable }\end{array}$ & & & CR & VE \\
\hline \multicolumn{6}{|l|}{ Work Family Conflict } \\
\hline \multirow{5}{*}{$\begin{array}{l}\text { a. WFC1 (Work to } \\
\text { Family Conflict MFC) }\end{array}$} & WFC1 & 0.62 & 0.61 & \multirow{5}{*}{0.86} & \multirow{5}{*}{0.55} \\
\hline & WFC2 & 0.80 & 0.35 & & \\
\hline & WFC3 & 0.90 & 0.20 & & \\
\hline & WFC4 & 0.66 & 0.56 & & \\
\hline & WFC5 & 0.70 & 0.51 & & \\
\hline \multirow{5}{*}{$\begin{array}{l}\text { b. WFC2 (Family to } \\
\text { Work Conflict/FWC) }\end{array}$} & FWC1 & 0.92 & 0.16 & \multirow{5}{*}{0.89} & \multirow{5}{*}{0.63} \\
\hline & FWC2 & 0.60 & 0.64 & & \\
\hline & FWC3 & 0.93 & 0.14 & & \\
\hline & FWC4 & 0.68 & 0.54 & & \\
\hline & FWC5 & 0.79 & 0.38 & & \\
\hline \multicolumn{6}{|l|}{$\begin{array}{c}\text { Organizational } \\
\text { Commitment (KO) }\end{array}$} \\
\hline \multirow{3}{*}{$\begin{array}{l}\text { a. KO1 (Affective } \\
\text { Commitment /AC) }\end{array}$} & $\mathrm{AC} 1$ & 0.74 & 0.45 & \multirow{3}{*}{0.81} & \multirow{3}{*}{0.59} \\
\hline & AC2 & 0.86 & 0.26 & & \\
\hline & AC3 & 0.69 & 0.53 & & \\
\hline \multirow{3}{*}{$\begin{array}{l}\text { b. KO2 (Contituance } \\
\text { Commitment/CC) }\end{array}$} & CC1 & 0.77 & 0.41 & \multirow{3}{*}{0.90} & \multirow{3}{*}{0.74} \\
\hline & CC2 & 0.89 & 0.20 & & \\
\hline & CC3 & 0.91 & 0.16 & & \\
\hline \multirow{3}{*}{$\begin{array}{l}\text { c. KO3 (Normative } \\
\text { Commitment/NC) }\end{array}$} & NC1 & 0.77 & 0.41 & \multirow{3}{*}{0.89} & \multirow{3}{*}{0.74} \\
\hline & $\mathrm{NC2}$ & 0.89 & 0.21 & & \\
\hline & NC3 & 0.91 & 0.16 & & \\
\hline \multicolumn{6}{|l|}{$\begin{array}{l}\text { Turnover Intention } \\
\text { (TOI) }\end{array}$} \\
\hline \multirow{4}{*}{ a. TOI1 } & TOI1.1 & 0.76 & 0.42 & \multirow{4}{*}{0.86} & \multirow{4}{*}{0.67} \\
\hline & TOI1.2 & 0.99 & 0.02 & & \\
\hline & TOI1.3 & 0.68 & 0.54 & & \\
\hline & TOI2.1 & 0.79 & 0.37 & & \\
\hline \multirow[t]{3}{*}{ b. TOI2 } & TOI2.2 & 0.99 & 0.02 & \multirow[t]{3}{*}{0.87} & \multirow[t]{3}{*}{0.70} \\
\hline & TOI2.3 & 0.69 & 0.52 & & \\
\hline & TOI3.1 & 0.70 & 0.51 & & \\
\hline \multirow[t]{2}{*}{ c. TOI3 } & TOI3.2 & 0.76 & 0.43 & \multirow[t]{2}{*}{0.78} & 0.54 \\
\hline & TOI3.3 & 0.74 & 0.45 & & \\
\hline
\end{tabular}

Sumber: Standardized output, Lisrel (n=117), 2020

Keterangan: CFA: Confirmatory Factor Analysis, CR: Construct Reliability, VE: Variance Extrated

Untuk menguji validitas indikator yang digunakan dalam penelitian ini, dilakukan dengan analisis faktor (factor loading) bertujuan menganalisis tingkat keandalan setiap item dalam mengukur suatu konstruk.
Peneliti melakukan serangkaian analisis faktor, dimana nilai dari masing-masing item pernyataan dan indikator dinyatakan valid apabila $\geq 0,5$. Jika dilihat dari tabel loading factor di atas dimana masing-masing 
item pernyataan dan indikator adalah $\geq 0,5$, maka item dapat dinyatakan valid dan dapat digunakan dalam pengukuran masingmasing indikator yang ada dalam penelitian ini. Sementara analisis Variance Extracted (VE) dan Construct Reliability (CR) dilakukan untuk menganalisis reliability indicator masing-masing konstruk. Dimana nilai dari VE dan CR harus > 0,5 untuk dapat dinyatakan reliabil dapat digunakan dalam penelitian ini.

Analisis selanjutnya yaitu menganalisis validitas dan reliabilitas konstruk dapat dilihat pada Tabel 3 berikut ini:

Tabel 3

Hasil Perhitungan Confirmatory Factor Analysis dan Reliability Konstruk Eksogen

\begin{tabular}{|c|c|c|c|c|c|}
\hline \multicolumn{2}{|c|}{ Model Pengukuran } & \multirow{2}{*}{$\begin{array}{l}\text { Factor } \\
\text { Loading }\end{array}$} & \multirow{2}{*}{$\begin{array}{l}\text { Measureme } \\
\text { nt Error }\end{array}$} & \multicolumn{2}{|c|}{ Reliability } \\
\hline $\begin{array}{c}\text { Laten } \\
\text { Variable }\end{array}$ & $\begin{array}{l}\text { Manifest } \\
\text { Variable }\end{array}$ & & & CR & VE \\
\hline Work Family & WFC & 0.96 & 0.08 & 0.96 & 0.93 \\
\hline Conflict (WFC) & FWC & 0.97 & 0.07 & 0.90 & 0.90 \\
\hline
\end{tabular}

Sumber: Standardized output, Lisrel (n=117), 2020.

Tabel 4

Hasil Perhitungan Confirmatory Factor Analysis dan Reliability Konstruk Endogen

\begin{tabular}{|c|c|c|c|c|c|}
\hline \multicolumn{2}{|c|}{ Model Pengukuran } & \multirow{2}{*}{$\begin{array}{l}\text { Factor } \\
\text { Loading }\end{array}$} & \multirow{2}{*}{$\begin{array}{c}\text { Measur } \\
\text { ement } \\
\text { Error }\end{array}$} & \multicolumn{2}{|c|}{ Reliability } \\
\hline Laten Variable & Manifest Variable & & & CR & VE \\
\hline \multirow{3}{*}{$\begin{array}{l}\text { Organizational } \\
\text { Commitment (KO) }\end{array}$} & $\mathrm{AC}$ & 0.86 & 0.27 & \multirow{3}{*}{0.96} & \multirow{3}{*}{0.85} \\
\hline & $\mathrm{NC}$ & 0.99 & 0.03 & & \\
\hline & $\mathrm{CC}$ & 0.99 & 0.03 & & \\
\hline \multirow{3}{*}{$\begin{array}{l}\text { Turnover Intention } \\
\text { (TOI) }\end{array}$} & TOI1 & 0.94 & 0.11 & \multirow{3}{*}{0.95} & \multirow{3}{*}{0.86} \\
\hline & TOI2 & 0.99 & 0.02 & & \\
\hline & TOI3 & 0.86 & 0.29 & & \\
\hline
\end{tabular}

Sumber: Standardized output, Lisrel (n=117), 2020.

Keterangan: CFA: Confirmatory Factor Analysis, CR: Construct Reliability, VE: Variance Extrated

Table 4 merupakan tabel uji validitas (baik validitas Indikator, validitas konstruk eksogen, dan endogen) dapat dilihat dari nilai hitung CFA melalui loading factor-nya (FL) $\geq 0,5$, Jika nilai FL kurang dari 0,5 maka item pertanyaannya harus dikeluarkan dari konstruk dan melakukan analisis faktor ulang. Sementara untuk menguji reliabilitas digunakan analisis $\mathrm{CR}$ dan VE, $\mathrm{CR}>0,7$ dan VE minimal 0,5 maka item memiliki reabilitas yang baik mengartikan bahwa terdapat kesamaan dan konvergensi variabel-variabel yang cukup dalam sebuah konstruk (Hair et al., 2010).

\section{Model Persamaan Structural SEM}

Berdasarkan figure 1 di bawah ini, diperoleh model persamaan structural: $\mathrm{OC}=-0,49^{*} \mathrm{WFC}$, Errorvar. $=0.76, \mathrm{R}^{2}=0.24$ $\mathrm{TOI}=-0.42 * \mathrm{KO}+0,47^{*} \mathrm{WFC}$, Errorvar. $=$

$$
0,40, R^{2}=0.60
$$

Berdasarkan persamaan model structural yang didapat maka dapat dianalisis sebagai berikut:

1. Persamaan structural pertama di atas dapat dianalisis bahwa besaran koefisen jalur dari variabel WFC terhadap variabel OC adalah sebesar $-0,49$, dengan besaran errorvar 0,76. Errorvar merupakan statistik 
kekeliruan atau kesalahan atas pengukuran variabel. Besaran $\mathrm{R}^{2}=0,24(24 \%)$ menunjukan bahwa secara parsial variabel laten WFC memiliki pengaruh yang negatif terhadap variabel OC, sementara sisanya sebesar 0,76 (76\%) dipengaruhi oleh variabel lain yang tidak diteliti dalam penelitian ini.
2. Persamaan structural kedua menunjukkan bahwa besarnya koefisien jalur variabel OC dan WFC terhadap variabel TOI adalah sebesar $-0,42$ dan 0,47 dengan besaran errorvar $=0.40$ (tingkat kekeliruan) dan $\mathrm{R}^{2}=0,60(60 \%)$.

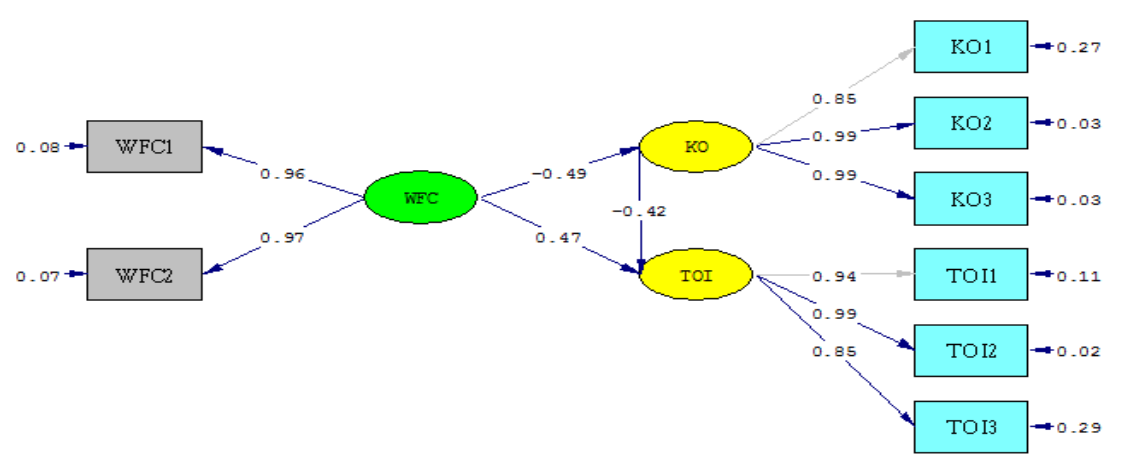

Chi-Square=17.53, df $=17, \mathrm{P}-$ value $=0.41931, \mathrm{RMSEA}=0.016$

Figure 1

Path Diagram Model Struktural

\section{Goodness of Fit (GOF)}

Tabel 5

Goodness of Fit (GOF)

\begin{tabular}{llll}
\hline \hline $\begin{array}{c}\text { Indicator } \\
\text { Pengukuran GOF }\end{array}$ & \multicolumn{1}{c}{ Cut of Value } & Hasil & Ket \\
\hline Chi Square & Diharapkan kecil & 18.61 & Good \\
RMSEA & $\leq 0.08$ & 0.02 & Good \\
GFI & $\geq 0.90$ & 0.96 & Good \\
AGFI & $\geq 0.80$ & 0.92 & Good \\
CFI & $\geq 0.90$ & 1.00 & Good \\
\hline
\end{tabular}

Sumber: Goodness of fit statistic, Lisrel, 2020.

Hasil uji GOF memberikan nilai dari masing-masing indikator pengukuran (chisquare 18,61, RMSEA dengan nilai 0,02 <0,08 (good, memenuhi syarat), GFI dengan nilai $0,96>0,90$ (good, memenuhi syarat), AGFI dengan nilai 0,92 >0.80 (good, memenuhi syarat), dan CFI dengan nilai 1,00 > 0,90 (good, memenuhi syarat) yang sesuai dengan ketentuan dari cut off value), sehingga disimpulkan bahwa model structural yang diajukan dalam penelitian ini dinyatakan fit terhadap data.

\section{Uji Pengaruh dan Uji Hipotesis}

Untuk menganalisis suatu hipotesis apakah diterima atau ditolak, dapat dilihat 
dari besarnya $t$ value. Jika $t$ value $>t$ table maka hipotesis yang diajukan diterima dan begitupun sebaliknya. Jika dilihat dari masing-masing nilai t value yang dihasilkan dari uji hipotesis pada Tabel 6 adalah masing-masing sebesar $t$ value $>1,657$, sehingga ke-empat hipotesis yang diajukan dalam penelitian ini diterima (didukung).

Berdasarkan hasil uji hipotesis yang telah dilakukan dapat disimpulkan bahwa keempat hipotesis yang diajukan dalam penelitian ini diterima. Dimana besaran pengaruh yang ditunjukkan dari hasil perhitungan standardized value, yaitu: 1) work family conflict berpengaruh negatif signifikan terhadap komitmen organisasi dengan nilai standardized $49 \%$ dengan tingkat signifikansi sebesar $0,05,2$ ) work family conflict berpengaruh positif signifikan terhadap turnover intention dengan nilai standardized $47 \%$ dengan tingkat signifikansi sebesar 0,05, 3) komitmen organisasi berpengaruh negatif signifikan terhadap turnover intention dengan nilai standardized $42 \%$ dengan tingkat signifikansi sebesar 0,05, 4) work family conflict berpengaruh positif signifikan terhadap turnover intention melalui mediasi komitmen organisasi dengan nilai standardized 21\% dengan tingkat signifikansi sebesar 0,05 .

Tabel 6

Uji Pengaruh dan Uji Hipotesis (menggunakan $t$ value)

\begin{tabular}{lllllllll}
\hline \hline No & $\begin{array}{l}\text { Eksogen } \\
\text { Variable }\end{array}$ & $\begin{array}{c}\text { Endogen } \\
\text { Variable }\end{array}$ & $\begin{array}{c}\text { Mediation } \\
\text { Variable }\end{array}$ & $\begin{array}{c}\text { Standardi } \\
\text { zed value }\end{array}$ & $\begin{array}{c}\text { Standard } \\
\text { Eror (SE) }\end{array}$ & $\begin{array}{c}\boldsymbol{t} \\
\text { value }\end{array}$ & $\begin{array}{c}\boldsymbol{t} \\
\text { table }\end{array}$ & $\begin{array}{c}\text { Hasil } \\
\text { Uji (a }= \\
\mathbf{0 . 0 5})\end{array}$ \\
\hline 1 & WFC & KO & - & -0.49 & 0.093 & -5.23 & 1.657 & sig \\
2 & WFC & TOI & - & 0.47 & 0.079 & 5.97 & 1.657 & sig \\
3 & KO & TOI & - & -0.42 & 0.076 & -5.58 & 1.657 & sig \\
4 & WFC & TOI & KO & 0.21 & 0.05 & 4.05 & 1.657 & sig \\
\hline
\end{tabular}

Sumber: standardized value, dan indirect effect, LISREL, 2020.

\section{Pembahasan}

Hasil penelitian saat ini didukung oleh hasil penelitian sebelumnya, yaitu: (1) Babakus et al., (2016), Fakhrana et al., (2016), Jaskyte dan Lee (2011), Oliver dan Brief (2017), Yousef (2012) yang menyatakan bahwa work-family conflict berpengaruh negatif signifikan terhadap komitmen organisasi, (2) Aboobaker et al. (2017), Noermijati et al. (2020) menyatakan bahwa work family conflict berpengaruh positif signifikan terhadap turnover intention, (3) Aydogdu dan Asikgil (2011); Finthariasari (2019), Labrague et al., (2018) menyatakan bahwa komitmen organisasi berpengaruh negatif signifikan terhadap turnover intention, (4) Sementara hipotesis keempat ini merupakan novelty dalam penelitian ini, dimana berdasarkan hasil uji hipotesis yang telah dilakukan variabel komitmen organi- sasi mampu memediasi antara variabel workfamily conflict dan turnover intention.

Work-family conflict yang terjadi pada karyawan merupakan bentuk konflik antar peran dimana tekanan peran dari pekerjaan dan domain keluarga saling bertentangan dalam beberapa hal, yaitu dalam melakukan pekerjaan atau peran keluarga sehingga membuat kesulitan untuk menjalankan peran keluarga atau pekerjaan tersebut. Melihat konsep ini dengan sudut pandang berbeda dimana karyawan yang menghabiskan lebih banyak waktu dan tenaga dalam satu peran dijadikan alasan untuk tidak melakukan atau memenuhi persyaratan dan tuntutan peran lain, dan akibat dari tekanan yang meningkat ini terjadi konflik antar peran dalam diri karyawan.

Teori Peran menyebutkan bahwa peran ganda dapat menyebabkan konflik pribadi, 
karena lebih sulit untuk melakukan setiap peran dengan cara yang baik. Ketika manajemen waktu menjadi tidak terkontrol serta kontradiksi dalam perilaku dan kekurangan energi, konflik muncul. Konflik antar peran ini dapat menyebabkan ketegangan pada individu. Pandangan mengenai Peran baik pekerjaan atau keluarga dapat memaksa individu untuk menguasai waktu dan kontradiksi dengan prospek peran pasti mempengaruhi peran lainnya (Shaffer et al., 2011). Allen dan Gale (2010) dan (Eby et al., 2015) bahwa konflik pekerjaan-keluarga terjadi ketika faktorfaktor yang berhubungan dengan masalah pekerjaan dapat membahayakan kehidupan keluarga misalnya ketidakpuasan hidup. Secara keseluruhan dapat disimpulkan bahwa konflik pekerjaan-keluarga dapat mempengaruhi secara negatif individu, keluarganya dan organisasi tempat dia bekerja (Shaffer et al., 2011).

Kemudian teori lain juga menyatakan bahwa konflik yang terjadi pada seseoang akan dapat diredam dengan adanya dukungan dan komitmen yang baik yang bersumber dari lingkungan sekitar. Komitmen organisasi dalam dua decade ini dikatakan sebagai sikap yang dominan dan merupakan subjek untuk dianalisis (María et al., 2015). Untuk menumbuhkan komitmen organisasi yang kuat dalam diri karyawan bukan sesuatu hal yang mudah melainkan butuh proses yang bertahap dan cukup panjang bagi organisasi yang bersangkutan. Hal ini dikarenakan banyak faktor yang dapat mempengaruhi komitmen karyawan terhadap organisasi, misalnya faktor personal, karakteristik pekerjaan, karakteristik struktur, dan pengalaman kerja.

Kondisi di lapangan yang tergambar dalam penelitian ini bahwa karyawan bank konvensional di Kota Bengkulu memiliki komitmen organisasi yang tinggi terhadap pekerjaan dan perusahaan. Dimensi normatif komitmen menunjukkan level yang tinggi perannya dalam mengurangi turnover intention karyawan, didukung dengan dimensi kontinuan komitmen dan afektif komitmen.
Karyawan bank konvensional Kota Bengkulu yang memiliki tanggung jawab dan berkewajiban dalam mengemban tugas mereka, ketergantungan dan merasa rugi jika meninggalkan perusahaan, menerima nilai-nilai yang ada di perusahaan, serta mereka yang memiliki keterikatan emosional pada perusahaan ini diyakini adalah faktor penyebab menurunnya tingkat turnover intention karyawan (Mercurio, 2015).

Banyak faktor yang membuat karyawan memiliki komitmen organisasi yang tinggi, namun yang perlu diingat bahwa alasan karyawan untuk tetap bekerja pada sebuah organisasi adalah bukan hanya berbicara persoalan finansial, akan tetapi bagaimana organisasi dapat mengikat karyawan dengan komitmen-komitmen yang tentunya dapat saling memberikan dampak positif terhadap karyawan dan organisasi. Ketika karyawan merasakan kenyamanan yang tidak pada level semestinya maka akan dapat mempengaruhi faktor organizational commitment.

Karyawan dengan tingkat komitmen yang rendah mencerminkan kurangnya tanggung jawab seseorang dalam menjalankan tugasnya. Mempersoalkan komitmen sama dengan mempersoalkan tanggung jawab, dengan demikian, ukuran komitmen seorang pimpinan terhadap keryawan yang dalam hal ini adalah terkait dengan pendelegasian wewenang (empowerment).

Dalam konsep ini pimpinan dihadapkan pada komitmen untuk mempercayakan tugas dan tanggung jawab pada bawahan. Sebaliknya, bawahan perlu memiliki komitmen untuk meningkatkan kompetensi diri (Salleh et al., 2015). Karyawan dengan komitmen yang tinggi tidak begitu memerlukan pengawasan yang lebih dari atasan sehingga hal ini akan sangat membantu perusahaan dalam rangka penghematan biaya pengawasan. Namun disisi lain, dalam hal mempertahankan kondisi komitmen organisasi karyawan yang baik ini, penting bagi perusahaan untuk dapat menyediakan kesempatan karyawan dengan menyediakan kesempatan pencapaian pres- 
tasi, mengembangan system penghargaan yang berfokus untuk kepentingan karyawan, serta mengintegrasikan tujuan individu dan organisasi.

Komitmen organisasi yang tinggi akan memunculkan berbagai perilaku yang menguntungkan bagi organisasi untuk mencapai tujuan dan meningkatkan produktifitas organisasi termasuk mengurangi tingkat turnover intention. Dengan kata lain, hubungan antara komitmen organisasi terhadap turnover intention adalah apabila seseorang karyawan memiliki komitmen yang tinggi dengan perusahaan menunjukkan seseorang karyawan tersebut mempunyai loyalitas, kesediaan untuk berusaha dengan sungguh-sungguh demi organisasi, serta mempunyai keinginan yang kuat untuk tetap menjadi anggota organisasi. Dengan demikian perilaku turnover intention dapat menurun dan dapat membantu seseorang karyawan mempertahankan kinerja organisasi dan membuat organisasi lebih efektif.

Strategi dalam konsep sumber daya manusia dapat dimulai dengan penyesuaian antara tujuan perusahaan secara keseluruhan dengan kondisi sumber daya manusia (karyawan) yang ada saat ini di lingkungan perusahaan. Untuk dapat menjadikan karyawan yang telah ada lebih bertalenta, parusahaan harus segera berencana untuk memberikan berbagai tambahan pelatihan dan pengembangan skill karyawan (Mercurio, 2015). Kemudian untuk kedepannya pada saat proses penerimaan karyawan baru, perusahaan menetapkan standar penerimaan karyawan berkaitan dengan kualitas bidang akademik dan skill yang dimiliki sesuai dengan job design yang ada di perusahaan, serta calon karyawan juga harus memiliki perilaku yang baik dan sopan.

Hal ini didukung oleh penelitian yang dilakukan (Labrague et al., 2018) dimana penelitiannya menunjukkan bahwa organizational commitment berhubungan langsung dengan variabel turnover intention. Hal ini diperkuat dengan hasil penelitian terdahulu yang menyatakan bahwa turnover intention dipengaruhi secara signifikan oleh organi- zational commitment ((Akinyemi, 2014); Chinomona dan Dhurup, 2015); María et al. (2015).

Temuan atas penelitian ini menunjukkan bahwa tingginya tingkat work family confict yang dialami oleh karyawan wanita perusahaan bank swasta syariah di saat wabah pandemi Covid-19. Family conflict muncul lebih besar skalanya dibandingkan dengan work conflict. Work-family conflict pada musim pandemi ini muncul karena faktor penyelesaian pekerjaan yang lebih rumit sementara kewajiban lain misalnya harus ekstra memperhatikan kesehatan pribadi dan keluarga, serta tidak adanya kesempatan untuk menikmati waktu luang diluar rumah bersama keluarga ditengah wabah pandemi ini semakin memicu stress sehingga mendorong terjadinya work-family conflict. Jika dilihat dari karakteristik responden work-family conflict ini lebih rentan terjadi pada karyawan dengan usia 31 - 45 tahun, dimana masa kerja 11-20 tahun, dan usia perkawinan 11-20 tahun. Greenhaus dan Powell (2012) bahwa karyawan dengan usia dibawah 40 tahun sangat rentan dengan gangguan pekerjaan dan stres kerja. Berbeda dengan Aboobaker et al., (2017) menyatakan bahwa mereka yang berusia lanjut di atas 40 tahun paling sedikit menghadapi WFC dan FCW. Sementara pernyataan Beutell (2010) bahwa karyawan dengan rentang usia dan rentang perkawinan demikian, dimana masih memiliki anak yang masih kecil akan mengalami workfamily conflict yang lebih besar dibandingkan dengan karyawan yang usianya lebih tua.

Setelah dikonfirmasi melalui wawancara mendalam kepada beberapa karyawan bahwa pada usia, masa kerja, dan usia perkawinan ini biasanya karyawan sedang ingin mengejar karir, mengejar promosi jabatan, dan kenaikan pangkat, sehingga membutuhkan fokus dalam bidang pekerjaan. Untuk mengejar karir, promosi jabatan, dan kenaikan pangkat, karyawan dituntut untuk dapat memenuhi target yang telah ditentukan oleh perusahaan sehingga sudah pasti mereka memiliki beban kerja 
yang lebih banyak. Oleh sebab itu fokus terhadap keluarga berkurang, sehingga muncul konflik yang disebut dengan workfamily conflict (Ekowati, 2018). Hal ini pula yang menyebabkan turnover intention karyawan wanita ini menjadi tinggi (meningkat).

Turnover intention ini muncul karena karyawan berfikir untuk mencari lowongan pekerjaan lain yang lebih longgar atau fleksibel waktunya, sehingga mereka tetap bisa bekerja menghasilkan uang namun juga memiliki waktu untuk memperhatikan keluarga Finthariasari (2019), Mlambo, 2013). Namun Finthariasari (2019) menyebutkan bahwa ada beberapa orang karyawan yang memilih untuk tetap tinggal. Dengan demikian komitmen organisasi yang ditunjukkan oleh karyawan wanita perusahaan bank swasta syariah di tengah wabah pandemi Covid-19 ini dianalisis pada level cukup baik.

Affective commitment yang dimiliki karyawan lebih baik dibandingkan dengan normative commitment dan contituance commitment. Affective commitment mengartikan keterikatan secara emosional positif yang dimiliki karyawan tinggi, mereka memiliki keinginan untuk tetap menjadi bagian dari organisasi atau perusahaan. Semantara alasan contituance karyawan untuk tetap pada pekerjaan yang ada saat ini adalah berkaitan dengan kekhawatiran mereka akan semakin sulitnya mencari pengganti pekerjaan pada musim pandemi ini. Komitmen organisasi juga dipengaruhi oleh karakteristik demografi seperti usia dan masa kerja kerja Finthariasari (2019) namun menurut Al Jabri dan Ghazzawi (2019) pengaruh ini tidak begitu kuat.

\section{SIMPULAN DAN SARAN \\ Simpulan}

Pada penelitian ini telah mengkonfirmasi bahwa: (1) WFC merupakan faktor yang berpengaruh signifikan terhadap turnover intention. Family conflict yang terjadi di masa pandemi Covid-19 ini mengkonfirmasi lebih tinggi dibandingkan dengan work family conflict, (2) Work family conflict berdampak negatif pada komitmen organisasi, dan (3) Sementara hasil penelitian berkaitan dengan peran mediasi komitmen organisasi ini, mengindikasikan adanya pengaruh yang positif antara work family confict dan turnover intention ini. Hal ini mengartikan secara statistik dikatakan memiliki pengaruh, namun jika dikaji secara teori hal ini mengartikan bahwa adanya mediasi komitmen organisasi ini belum mampu menurunkan turnover intention karyawan wanita perusahaan bank swasta syariah di saat wabah pandemi Covid-19.

\section{Saran}

Studi ini dilakukan selama pandemi Covid-19 pada karyawan wanita perusahaan perbankan syariah swasta yang ada di Kota Bengkulu berkaitan dengan work family conflict yang terjadi di masa pandemi ini, sehingga pada masa yang akan datang kondisi bidang pekerjaan dan keluarga dapat berubah setelah masa pandemi ini berakhir. Peneliti selanjutnya dapat melakukan penelitian baru untuk mengkonfirmasi kondisi work family conflict maupun perilaku lain yang dapat berhubungan dengan turnover intention karyawan. Sampel yang digunakan hanya sebanyak 117 karyawan karena saat ini adanya keterbatasan waktu dan komunikasi. Para peneliti selanjutnya dapat memperluas jumlah responden dan lokasi penelitian missal, karyawan pada sektor industri, jasa asuransi, maupun work family conflict pada sektor pendidikan di tingkat perguruan tinggi.

Dalam rangka meningkatkan organizational commitment organisasi dapat melakukan pengikatan dengan melaksanakan kegiatan peningkatan kompetensi karyawan melalui pelatihan dan pengembangan skill. Hal ini dinilai efektif untuk menurunkan tingkat perpindahan (turnover) karyawan. Memotivasi karyawan dan menumbuhkan nilai-nilai positif dalam bekerja sehingga menimbulkan semangat kerja dan job embededdness pun meningkat. Memunculkan rasa kehangatan dalam organisasi dan 
mempererat tali persahabatan antar karyawan, sehingga membuat mereka merasa saling memiliki. Hal ini juga dapat menjadi efektif dalam rangka mengurangi kejenuhan karyawan yang dapat menimbulkan niat berpindah (turnover intention) dan berujung pada perpindahan (turnover) karyawan.

Temuan ini dapat dijadikan acuan bagi perusahaan untuk dapat mengembangkan konsep management conflict dalam perusahaan yang melibatkan Human Resource Leaders untuk sama-sama memahami bagaimana permasalahan yang dapat muncul pada karyawan terutama pada pekerjaan. Perusahaan ini dapat mengembangkan konsep company citizenship atau yang biasa disebut organizational citizenship behavior $(O C B)$ yaitu dengan membuat perusahaan seperti sebuah keluarga dan kediaman yang nyaman bagi para karyawan dalam melakukan pekerjaannya. Perilaku $O C B$ ini dinilai sangat efektif untuk meningkatkan kinerja dan produktifitas, serta efektifitas perusahaan karena perilaku ini dilakukan karyawan melebihi tuntutan atas kontribusi karyawan di luar sistem reward yang normal. Hal lain yang dapat dilakukan perusahaan dalam rangka mewujudkan company citizenship adalah dengan memahami motif karyawan dalam berperilaku $O C B$ itu sendiri. Menurut para pakar, ada beberapa motif seseorang berperilaku $O C B$ diantaranya motif berprestasi, motif afiliasi, dan motif kekuasan. Motif berprestasi dilakukan oleh orang-orang yang memiliki sikap perfeksionis. Motif afiliasi dilakukan seseorang untuk membangun hubungan dengan banyak orang. Dan motif kekuasaan, dimana seseorang bertindak atau bekerja hanya ingin mencari status. Dengan memahami perilaku karyawan, perusahaan dapat menghindari bahaya yang dapat terjadi karena persoalan turnover karyawan.

\section{Keterbatasan Penelitian}

Penelitian ini dilakukan pada saat masa pandemi Covid-19 terjadi di dunia. Dimana dampak psikis yang terjadi pada wanita pekerja terutama di perusahaan perbankan swasta adalah peran ganda yang harus dilakukan, yaitu sebagai karyawan atau pekerja dan sebagai istri dan ibu untuk anakanak mereka. Penelitian selanjutnya dapat dilakukan dengan kondisi yang tentunya berbeda dengan saat pandemi ini. Peneliti selanjutnya dapat menganalisis berbagai variabel lain, seperti variabel dukungan atasan dan rekan kerja dalam rangka mengurangi niat berpindah (turnover intention). Penelitian selanjutnya juga dapat menganalisis work-family conflict, komitmen organisasi, turnover intention dengan meninjau dari karakteristik usia, usia perkawinan, dan lama bekerja.

\section{DAFTAR PUSTAKA}

Aboobaker, N., M. Edward, dan K. P. Pramatha. 2017. Work-family Conflict, Family-work Conflict and Intention to Leave the Organization: Evidences Across Five Industry Sectors in India. Global Business Review 18(2): 524-536. https://doi.org/10.1177/097215091666 8696.

Akinyemi, B. 2014. Organizational Commitment in Nigerian Banks: The Influence of Age, Tenure and Education. Journal of Management and Sustainability 4(4).

Al-Zawahreh, A. dan F. Al-Madi. 2012. The utility of equity theory in enhancing organizational effectiveness. Journal of Economics, Finance And Administrative Sciences 46: 158-170.

Al Jabri, B. dan I. Ghazzawi. 2019. Organizational Commitment: A Review of the Conceptual and Empirical Literature and a Research Agenda. International Leadership Journal 11(1): 78119.

Allen, F. dan D. Gale. 2010. Financial contagion. Journal of Political Economy 108: 1-23.

Allen dan Meyer. 2013. The Measurement and Antecedents of Affective, Contintinuance and Normative Commitment to Organitazion. PT Elex Media Komputindo, Jakarta.

Allen, T., R. C. DJohnson, K. N. Saboe, E. 
Cho, S. Dumani, dan S. Evans. 2012. Dispositional variables and workfamily conflict: A meta-analysis. Journal Of Vocational Behavior 80: 17-26.

Alsam, N., R. Imran, M. Anwar, Z. Hameed, dan A. Kafayat. 2013. The impact of work family conflict on turnover intentions: An empirical evidence from Pakistan. World Applied Sciences Journal 24(5): 628-633. https://doi.org/10. 5829/idosi.wasj.2013.24.05.13227

Amstad, F. T., L. L. Meier, U. Fasel, A. Elfering, dan N. K. Semmer. 2011. A Meta-Analysis Of Work-Family Conflict And Various Outcomes With A Special Emphasis On Cross-Domain Versus Matching-Domain Relations. Journal of Occupational Health Psychology 16: 151169.

Ashforth, B. E., K. M. Rodgers, M. G. Pratt, dan C. Pradies. 2014. Ambivalence in organizations: A multilevel approach. Organization Science 25: 1453-1478.

Aydogdu, S. dan B. Asikgil. 2011. An empirical study of the relationship among job satisfaction, organizational commitment and turnover intention. International Review of Management and Marketing 1(3): 43-53.

Babakus, E., S. W. Cravens, M. Johnston, dan W. C. Moncrief. 2016. Examining the Role of Organizational Variables in the Salesperson Job Satisfaction Model. Journal of Personal Selling $\mathcal{E}$ Sales Management 16(3): 33-46.

Benligiray, S. dan H. Sönmez. 2012. The International Journal of Human Analysis of organizational commitment and work - family conflict in view of doctors and nurses. The International Journal OfHuman Resource Management 23(18): 3890-3905.

Beutell, N. J. 2010. Work Schedule, Work Schedule Control And Satisfaction In Relation To Work Family Conflict, Work Family Synergy, And Domain Satisfaction. Career Development International 15(5): 501-518.

Chinomona dan Dhurup. 2015. The Role of
Organisational Commitment in the Organisational Citizenship Behaviour and Employee Intention to Stay Relationship: The Case of Zimbabwe. International Journal of Humanities and Social Science 5(7).

Eby, L., W. Casper, A. Lockwood, C. Bordeaux, dan A. Brinley. 2015. Work and family research in IO/OB: Content analysis and review of the literature (1980-2002). Journal of Vocational Behaviour 66: 124-137.

Ekowati, S. 2018. Model Of Work Family Conflict (A Study On Bank Employee In Bengkulu City). University of BengkuluIndonesian.

Fakhrana, Z. N., A. Naryoso, D. Purbaningrum, dan N. Lailiyah. 2016. Pengaruh Intensitas Komunikasi Antarpribadi dan Tingkat Kecemburuan Terhadap Kualitas Hubungan Asmara Pasangan LDR (universitas Diponegoro). http://dating. lovetoknow.com.

Finthariasari, M. 2018. Determinant Factor And Development Of Strategy Model Of Turnover Intention On Banking In Bengkulu City. 3rd International Conference of Graduate School on Sustainability (ICGSS).

Finthariasari, M. 2019. Variabel Employee Engagement, Organizational Commitment, $\mathrm{Job}$ Embededdness, OCB, \& Turnover Intention Pada Karyawan Perbankan Konvensional Kota Bengkulu. Universitas Bengkulu.

Greenhaus, J. H. dan T. D. Allen. 2011. Workfamily balance: A review and extension of the literature. In Handbook Of Occupational Health Psychology (In J. C. Q: 165-183). American Psychological Association.

Greenhaus, J. H. dan G. N. Powell. 2012. The family-relatedness of work decisions: A framework and agenda for theory and research. Journal of Vocational Behavior 80: 246-255.

Greenhaus, J. H. dan G. N. Powell. 2016. When work and family are allies: A theory of work-family enrichment. 
Academy of Management Review 31(1): 7292.

Hair, J., W. Black, B. Babin, dan R. Anderson. 2010. Multivariate data analysis: A global perspective (7th ed.). Pearson.

Higgins, C. A., L. E. Duxbury, dan S. T. Lyons. 2010. Coping With Overload and Stress: Men and Women in Dual-Earner Families. Journal Of Marriage And Family, 72(4), 847-859. https://doi.org/10. 1111/j.1741-3737.2010.00734.x.

Hom, P., T. Lee, J. Shaw, dan J. P. Hausknecht. 2017. One hundred years of employee turnover theory and research.

Jaskyte, K. dan M. Lee. 2011. Organizational Commitment of Social Workers: An Exploratory Study. Administration in Social Work 33(3): 227-241.

Karatepe, O. M. dan O. Uludag. 2008. Affectivity, Conflicts In The WorkFamily Interface And Hotel Employee Outcomes. International Journal of Hospitality Management 27: 30-41.

Kopelmen, R., J. Greenhaus, Connolly, dan F. Thomas, F. 1983. A Model Of Work, Family, And Interrole Conflict: A Construct Validation Study. Organization Behavior $\mathcal{E}$ Human Performance 32(2): 198-215.

Kossek, E. E., K. H. Lee, E. E. Kossek, dan K. H. Lee. 2017. Work-Family Conflict and Work-Life Conflict. Oxford Research Encyclopedia of Business and Management, May, 1-23. https://doi.org/10.1093/ acrefore/9780190224851.013.52

Labrague, L. J., D. M. McEnroe - Petitte, K. Tsaras, J. P. Cruz, P. C. Colet, dan D. S. Gloe. 2018. Organizational commitment and turnover intention among rural nurses in the Philippines: Implications for nursing management. International Journal of Nursing Sciences 5(4): 403-408. https://doi.org/10.1016/j.ijnss.2018.09. 001

Lepold, A. 2018. Expectations of Bank Employees on the Influence of Key Performance Indicators and The Relationship with Job Satisfaction and Work Engagement, Soc. Sci. 2018, 7, 99.
Social Journal, 99(7). https://doi.org/10. 3390/socsci7060099

Mansour, S. dan D. G. Tremblay. 2018. Work-Family Conflict/Family-Work Conflict, Job Stress, Burnout And Intention To Leave In The Hotel Industry In Quebec (Canada): Moderating Role Of Need For Family Friendly Practices As "Resource Passageways." The International Journal of Human Resource Management 29(16): 2399-2430. https://doi.org/org/10.1080/09585192. 2016.1239216

María, Z. O., R. Ernesto, M. Eulalia, dan G. Pablo Colón. 2015. Relationship Between Organizational Commitments And Organizational Citizenship Behaviour In A Sample Of Private Banking Employees. International Journal of Sociology and Social Policy 35(2): 91-106.

Mercurio, Z. A. 2015. Affective Commitment as a Core Essence of Organizational Commitment An Integrative Literature Review. Human Resource Development Review 14(4).

Mlambo, L. 2013. Impact Of Psychological Factors On Employee Turnover Intention. International Journal of Research In Commerce Economics \& Management, 1041(3).

Netemeyer, R., J. Maxham, dan C. Pulig. 2015. Conflict in The Work-Family Interface: Links To Job Stress, Cutomer Service, Employee Performance, And Customer Purcase Intent. Journal of Marketing 69(April): 130-143.

Ngo-Henha, P. E. 2017. A Review of Existing turnover Intention Theoris. International Journal of Economics and Management Engineering 11(11): 2751-2758.

Noermijati, N., S. Wongviboonrath, dan W. Itlay, A. Sudiro. 2020. Work-Family Conflict, Job Engagement, Emotional Exhaustion: Their Influence On The Turnover Intention Of Indigenous Papuan Female Employees. Journal of Applied Management 8(1): 1-13.

Oliver, R., dan A. Brief. 2017. Determinants And Consequences Of Role Conflict and 
Ambiguity Among Retail Sales Managers. Journal of Retailing 53(4): 47-58.

Rathakrishnan, N. TInim, dan T. Kok. 2016. Turnover Intentions of Lecturers in Private Universities in Malaysia. Pertanika. Journal of Social Sciences $\mathcal{E}$ Humanities.

Salleh, R., M. S. Nair, dan H. Harun. 2015. Job Satisfaction, Organizational Commitment, and Turnover Intention: A Case Study on Employees of a Retail Company in Malaysia. International Journal of Economics and Management Engineering 6(12).

Shaffer, M., J. Joplin, dan Y. Hsu. 2011. Expanding the boundaries of workfamily research: A review and agenda for future research. International Journal of Cross Cultural Management 11: 221-268.

Wage Institution. 2010. Fresh Labour Market Data On National Wage Indicator Websites. https://wageindicator.org/Wageindica torfoundation/WageIndicatorgazette/2 010/news-items-2010/fresh-labourmarket-data-on-national-wage- indicator-websites-october-2010

Wilson, K. S. dan H. M. Baumann. 2014. Capturing a More Complete View of Employees' Lives Outside of Work: The Introduction and Development of New Interrole Conflict Constructs. Personel Psychology 68(2): 235-282.

Yanchus, N. J., L. T. Eby, C. E. Lance, dan S. Drollinger. 2010. The Impact Of Emotional Labor On Work-Family Outcomes. Journal of Vocational Behavior 76: 105-117.

Yousef, D. 2012. Job Satisfaction As A Mediator Of The Relationship Between Role Stressors and Organizational Commitment: A Study From An Arabic Cultural Perspective. Journal of Managerial Psychology 17(4): 250-266.

Zhao, X. R., H. Qu, dan R. Ghiselli. 2011. Examining The Relationship Of WorkFamily Conflict To Job And Life Satisfaction: A Case Of Hotel Sales Managers. International Journal of Hospitality Management 30: 46-54. 